\section{Filippova, Olga Nikolaevna}

The Polytechnic Museum,

Moscow, Russian Federation

\section{Филиппова Ольга Николаевна}

Политехнический музей,

г. Москва, Российская Федерация

\title{
ПЕЙЗАЖ В ТВОРЧЕСТВЕ ВАСИЛИЯ ПЕРЕПЛЁТЧИКОВА
}




\section{АННОТАЦИЯ}

Целью данной статьи является раскрытие творческой биографии Василия Васильевича Переплётчикова как пейзажиста-лирика. Рассмотрен творческий путь художника, одаренного в различных областях изобразительного искусства (живопись, графика), литературы (проза, стихи), обладавшего острым умом, наблюдательностью, желанием разнообразных свершений в художественной жизни (организовывал выставки, участвовал в создании новых объединений). Кроме того, В.В. Переплётчиков был увлеченным путешественником, что нашло отражение во всем его творчестве, одной из главных тем в котором был Север. Последовательно проанализированы пейзажные рисунки, картины и этюды разных периодов творчества художника, отмечены характерные черты. В качестве основного в данном исследовании использован историко-биографический метод.

КЛЮЧЕВЫЕ СЛОВА: ЖИВОпИСЬ; ИЗобразитеЛьное искусство; В.В. Переплётчиков; пейзаж.

\begin{abstract}
The purpose of this article is to reveal the creative biography of Vasily Vasilyevich Perepletchikov as an landscape lyricist. The article analyzes the difficult creative path of the artist, who was generously gifted in various fields of fine art (engaged in painting and graphics), literature (wrote prose and poetry), had a sharp mind, observation, desire for various achievements in artistic life (organized exhibitions, participated in the creation of new associations). In addition, he was a keen traveler, which is reflected in all his work, one of the main themes in which was the North. Landscape drawings, paintings and sketches of different periods of the artist's work are consistently analyzed, characteristic features are noted. The historical and biographical method was used as the main one in this study.
\end{abstract}

KEYWORDS: painting; fine art; Vasily Perepletchikov; landscape. 


\section{Введение}

В.В. Переплётчиков, являясь учеником И.И. Шишкина и В.Д. Поленова, был весьма заметной фигурой в Союзе русских художников, его членом-учредителем. Одной из главных тем в его творчестве был Север, куда Василий Васильевич впервые отправился в 1902 году и на протяжении двенадцати лет ежегодно летом посещал полюбившиеся ему места, вооружившись этюдником и записной книжкой. В справочной литературе отмечается, что «пейзажные произведения В.В. Переплётчикова в предреволюционное время приобретались многими коллекционерами, среди них назовем Д.В. Высоцкого, В.О. Гиршмана, Н.А. Львова, М.К. Морозову, М.П. Рябушинского, К.Т. Солдатенкова. Список этот можно было бы расширять и далее» [12]. Среди исследователей, которые упоминают имя В.В. Переплётчикова в ряду художников «московской школы», важно отметить В.С. Манина, В.П. Лапшина, Г.Ю. Стернина, В.А. Дудакова, Б.М. Одинцова, Е.А. Скоробогачеву, А.В. Федотову, М.С. Чижмак и др. [2; 3; 4; 6; 13; 14; 15; 16; 17; 18]. По мнению В.С. Манина, автора вступительной статьи «В.В. Переплётчиков и его дневники», через отношение мемуариста к событиям очень выпукло осязается время, «и по мере того как зреет в В.В. Переплётчикове художник, совершенствуется его литературное мастерство» [7, с. 6]. В.П. Лапшин так оценивает значение разных сторон деятельности художника для его современников: «...В.В. Переплётчиков был фигурой примечательной, активно участвовавшей в художественной жизни Москвы и Петербурга на протяжении более двух десятилетий. Такие мастера, как И.И. Левитан, М.В. Нестеров и другие, чтили его не только как художника, но и как общественного деятеля. Он известен был и как литератор» [3, с. 48].

Исследований непосредственно произведений художника не так много. Так, В.А. Дудаков в статье «Выставка шести» обращает внимание на ученичество В.В. Переплётчикова у И.И. Шишкина и интерес к натурному пейзажу и стилистике передвижников [2]. Анализируются также его лирические произведения, с предельной точностью фиксирующие конкретный пейзаж, состояние природы. Г.Ю. Стернин в своем труде «Художественная жизнь России 1900-1910-х годов» пишет о «русской теме» или, лучше сказать, теме России в произведениях мастера: «Она, эта тема, роднила между собой, например, сделанные на натуре северные пейзажи А.Е. Архипова и В.В. Переплётчикова...» [16, с. 152]. В каталоге «Московские художники конца XIX - начала XX века», составленном Б.М. Одинцовым, также сказано, что «всю жизнь В.В. Переплётчиков много путешествовал по России, но особенно он любил Русский Север. В природе он видел не только источник вдохновения, но и эталон прекрасного. Поэтому в своих картинах, а не только в этюдах, В.В. Переплётчиков с предельной точностью воспроизводит пейзажи конкретных географических пунктов и то состояние атмосферы, погоды, которое он зафиксировал в своей памяти или этюде» [6, с. 22]. Эта же тема отмечена и в исследованиях А.В. Федотовой, Е.А. Скоробогачевой: «Одной из значимых тем для него является воссоздание образов Русского Севера, как в живописи и графике, так и в литературе» [14, с. 124].

Между тем детальных исследований, посвященных пейзажу в творчестве В.В. Переплётчикова, пока нет. Целью данной статьи является раскрытие творческой биографии В.В. Переплётчикова как пейзажиста-лирика, что представляется актуальным в силу недостаточной исследованности вопроса. В работе используется историко-биографический и элементы ряда искусствоведческих методов, с помощью которых анализируются произведения художника.

\section{Обсуждение}

Василий Васильевич Переплётчиков родился в Москве у Красных ворот 18 октября 1863 года, и его жизнь «изначально была отмечена московскими традициями. Он родился в купеческой семье» [12]. В.П. Лапшин так пишет о начале становления художника: «Первоначальное образование Василий Переплётчиков получил в Практической Академии коммерческих наук. Еще находясь в Академии, он почувствовал интерес к занятиям искусством и начал брать частные уроки у передвижника А.А. Киселёва. Вслед за тем поступил в Училище живописи, ваяния и зодчества, где стал изучать архитектуру. Знакомство с И.И. Шишкиным заставляет В.В. Переплётчикова еще раз изменить род занятий. Оставив архитектуру, он посвящает себя целиком изобразительному искусству, пробуя свои возможности в графике и живописи» [3, с. 48]. В этом же исследовании автор отмечает: «Его жизнь той ученической (и последующей тоже) поры - обратим на это внимание - в отличие от большинства коллег по искусству была материально благополучной, и уже в каталогах ранних выставок он (редкий случай для молодого художника) указывал постоянный адрес: "Против Яузских ворот, Хлудовский тупик, собственный дом". Такое независимое положение, казалось бы, должно облегчать ему занятия избранной профессией, но это же, может быть, больше всего станет мешать В.В. Переплётчикову в реализации 
своих художественных возможностей. Он впоследствии не уставал себя пробовать в других областях. И отнюдь не безуспешно, так как был несомненно одарен» [3, с. 48].

Важны первоначальные профессиональные интересы В.В. Переплётчикова, которые были обращены в основном к графике: «В 1880-1890-е годы он много времени уделяет рисунку, изучает различные техники графического искусства (пастель, уголь, перо, карандаш, литографию, акварель), участвует совместно с С.В. Ивановым в деятельности рисовальных классов (1888). Увлечение графикой в среде коллег В.В. Переплётчикова было столь велико, что ими даже был создан "Периодический выпуск рисунков русских художников". В первом, изданном в этом ряду, альбоме (1886) поместили рисунки С.В. Иванова, С.А. Коровина, И.И. Левитана, В.А. Симова, А.С. Степанова и др. В.В. Переплётчиков тоже участвовал в нем. Он показал литографию "Кама у Пьяного бора”. Спустя пять лет, в 1891 году В.В. Переплётчиков выпускает самостоятельный альбом пейзажных рисунков (перо, уголь, карандаш) [9], говорящих о внимательном изучении творчества И.И. Шишкина» [12]. Преданность натуре В.В. Переплётчиков унаследовал от своего учителя И.И. Шишкина, но в отличие от последнего В.В. Переплётчиков - пейзажист-лирик: лирические мотивы преобладают в его пейзажах. Альбом был замечен современниками, о нем написаны хорошие отзывы. «В эти же годы В.В. Переплётчиков вместе с А.А. Киселевым, Н.А. Клодтом, Л.О. Пастернаком, А.С. Степановым и И.И. Шишкиным принимает участие в графическом оформлении московского журнала изящных искусств и литературы "Артист", выполняет рисунки в литературном сборнике (1892) и т.д.» [12].

В 1880 году В.В. Переплётчиков впервые показал свои работы на ученической выставке, а с 1884 года он активно участвует в выставках Московского общества любителей художеств, Московского товарищества художников, Товарищества передвижных художественных выставок, петербургского Общества русских акварелистов. С января 1895 года у В.В. Переплётчикова чувствуется перелом в отношении к творчеству. Состоялась его поездка за рубеж, которая оказала на художника более существенное влияние, чем он сам предполагал. О встречах с В.В. Переплётчиковым в Мюнхене в 1896 году рассказывает И.Э. Грабарь, который поступил в том же году в частную школу-студию Антона Ажбе. Художник познакомился с современным искусством, очевидно с немецким, с импрессионистами, воздействие которых будет заметно в его творчестве несколько позже. В 1899-1903 годах его работы выставляются и на выставках «Мир искусства». Этот этап творчества Василия Васильевича представлен на выставке такими картинами и этюдами, как «Пасмурный день», «На Волге», «Оттепель», «Дорога в лесу». В.В. Переплётчиков был одним из главных инициаторов устройства выставок 36-ти художников и членом-учредителем Союза русских художников. А.В. Федотова отмечает, что «на протяжении более чем десятилетнего периода В.В. Переплётчиков систематически показывал на выставках (главным образом "Союза русских художников") северные пейзажи, что позволило современникам назвать его "Восторженным певцом дальнего Севера"» [17, с. 116].

Параллельно с графикой В.В. Переплётчиков много занимается станковой живописью, ездит вместе с И.И. Левитаном в Саввинскую слободу под Звенигородом, с С.А. Виноградовым в Плёс на Волгу и т.д. Он необычайно работоспособен. Творчество В.В. Переплётчикова как живописца было небезразлично современникам: «В 1896 году И.И. Левитан сообщит А.В. Васнецову, что В.В. Переплётчиков "недурные этюды сработал”. А.Н. Бенуа, несколькими годами позже, отмечая работы В.В. Переплётчикова и некоторых москвичей - последователей И.И. Левитана, скажет, что их пейзажи "будут так же цениться со временем, как бесчисленные и милые "малые голландцы"'. О работах В.В. Переплётчикова не только пишут критики, их воспроизводят в журналах и особенно часто в "Мире искусства" - журнале, который так чутко реагирует на появление "новой волны" в русской живописи. Произведения художника приобретал "сам" П.М. Третьяков, покупал "сам" С.П. Дягилев» [12].

Так, в 1896 году с XXIV выставки Товарищества передвижных художественных выставок П.М. Третьяков приобретает пейзаж «Зимой в лесу» (1895; рис. 1), а на следующий год другую картину, «Начало весны» (1896) [7, с. 9]. Можно только предположить, какой подъем это вызвало у художника, который моментально согласился с предложенной П.М. Третьяковым ценой и рад был сообщить ему все необходимые биографические данные. На картине «Зимой в лесу» (1895) мы видим скромную русскую природу, а В.В. Переплётчиков показывает себя как мастер находить прекрасное в простом [7, с. 9].

Как этой работе, так и многочисленным этюдам и рисункам предшествующего времени свойственна демократическая трактовка пейзажа. Демократизм воззрений, приобретенный, очевидно, еще в годы ученичества, художник сохраняет до конца жизни. Во втором произведении, купленном П.М. Третьяковым, - «Начало весны» (1896) пейзаж оставляет впечатление случайности найденного мотива [7, с. 9]. 


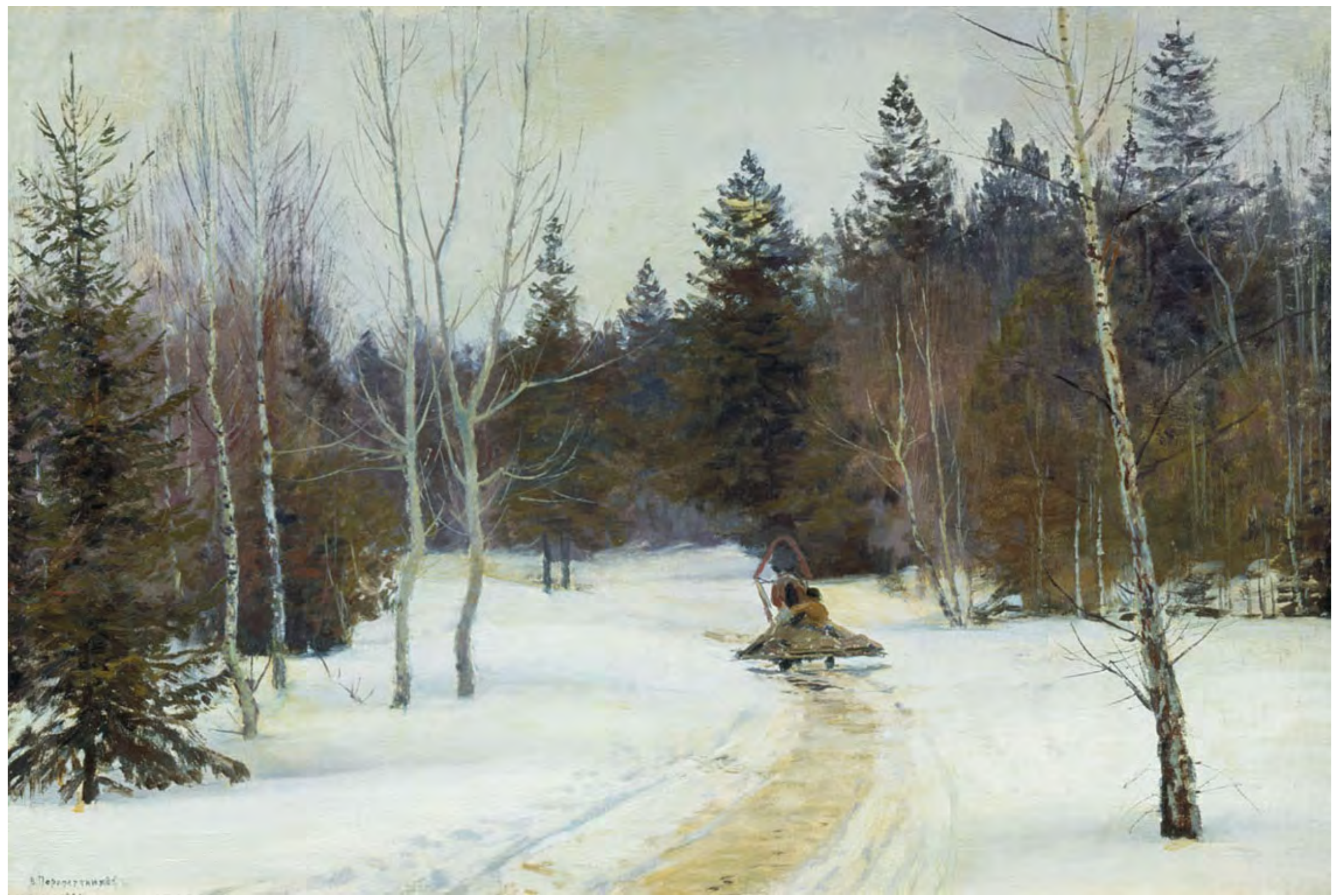

Всё детально и точно выписано, отсутствуют оригинальное построение, выразительные ракурсы, цветовые находки - всё то, что рождает своеобразие и неповторимость искусства. Такая обыденность может быть оправдана сознательным стремлением художника показать природу, ничем не примечательную, как окружение нашей жизни. В его многочисленных работах это часто встречается и даже производит эффект, но в пейзаже «Начало весны» такой подход привел к натурализму, однообразной, почти фотографической приземленности [7, с. 10]. В это время художник стремится создать картину и не ограничиваться одними лишь этюдами. Поэтому летом он пишет этюды с натуры, чтобы использовать их зимой как первичный материал для живописного полотна. Его довольно простые пейзажи 1897-1898 годов «Урал», «На реке», «Река» не лишены настроения, созданного самой действительностью (рис. 2, 3, 4). Можно сказать, что художник составлял только звуки природы, натура не преображалась его воображением. В 1899 году он написал художественную, эпически звучную, значительную по настроению картину «Пейзаж», которая сейчас находится в Государственной Третьяковской галерее. В ней он показал себя мастером национального пейзажа.

Всю жизнь В.В. Переплётчиков много путешествовал по России, в частности в Архангельскую и Вологодскую губернии, и как неоднократно отмечалось, особенно он любил Русский Север. Его своеобразная красота, строгое безмолвие и широкое раздолье увлекают художника. В книге «Север. Очерки русской действительности» [9], изданной гораздо позже ее написания (издание 2012 года «Дневник художника» является ее репринтным изданием; переиздано в 2019 [11]), сказано, что художник приезжал на Русский Север в 1902
1. В.В. Переплетчиков. Зимой в лесу.

1895.

Холст, масло.

$39 \times 58$.

Государственная

Третьяковская галерея. Фото: artsait.ru 


\section{ART OF THE

2. В.В. Переплетчиков. Урал.

1897.

Холст, масло.

$94,5 \times 140$.

Государственный

художественный музей

Алтайского края.

Фото: yavarda.ru

3. В.В. Переплетчиков.

\section{На реке.}

1897.

Картон, масло.

$12 \times 20$.

Частная коллекция

Фото: artpoisk.info
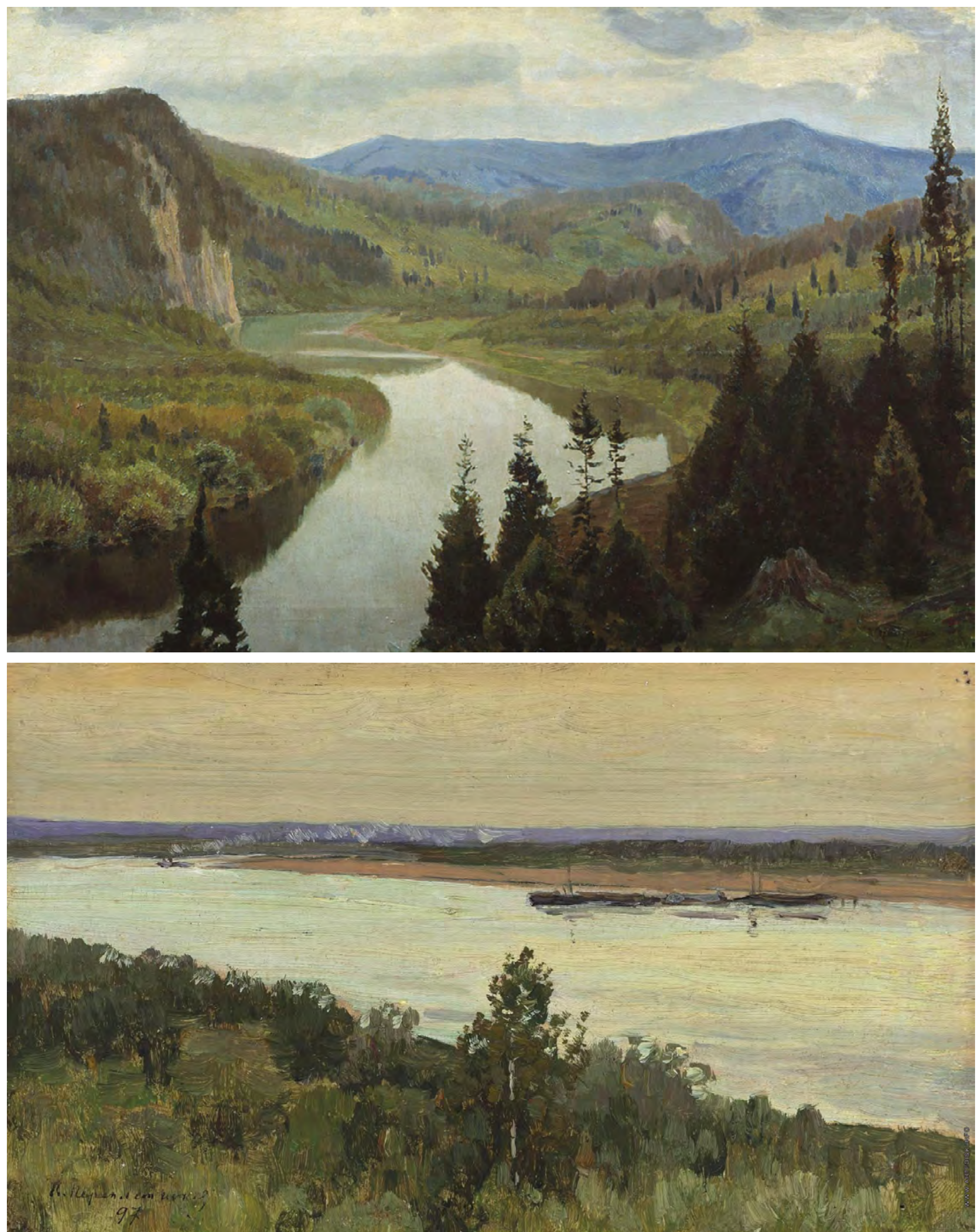
4. В.В. Переплетчиков. Река.

1898.

Холст, масло.

$55 \times 86$.

Вятский

художественный музей имени

В.М. и А.М. Васнецовых. Фото: yavarda.ru

\section{5. В.В. Переплетчиков.} Базар в Архангельске. 1902.

Холст, масло.

41,4 × 59,4.

Государственная

Третьяковская галерея.

Фото: colta.ru

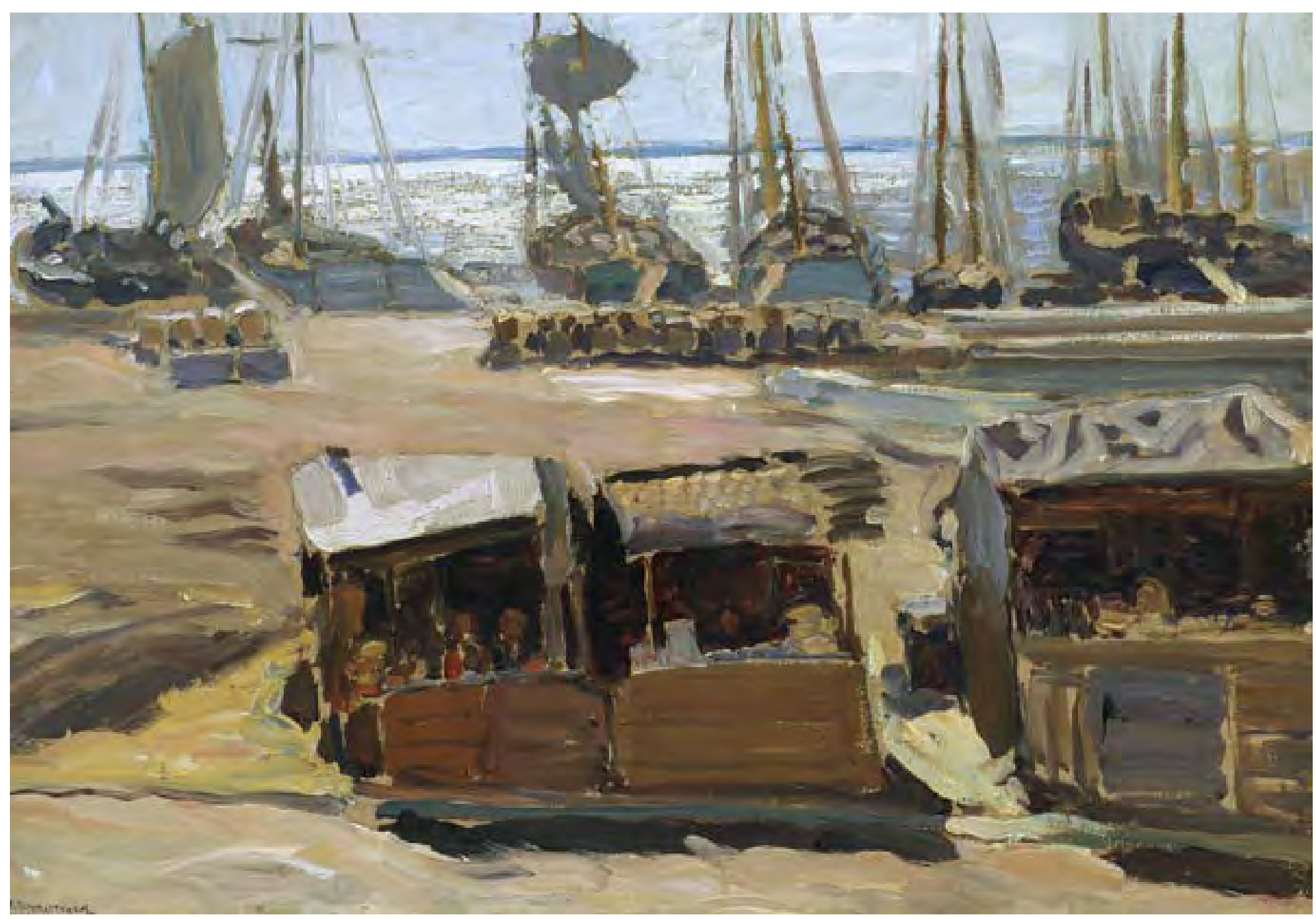


и в 1913 году. По результатам первой поездки, которая проходила по территории Архангельской области, был написан этюд «Базар в Архангельске» (1902; рис. 5), в котором прослеживается оставшаяся смысловая связь с передвижничеством [7, с. 14]. Несколькими свободными взмахами кисти художник добивается цветового эффекта. В результате появляется ощущение воздуха, пространства, света. Это действительно этюдный подход к природе. Только теперь этюд служит не для фиксации деталей, а для передачи воздуха и света. Он бесконечно динамичен, сверкает бликами. Подход к натуре становится импрессионистическим. Видно, что живописец находится на пути к новому этапу творчества, к пластическому решению образа природы.

Об этом периоде так говорит автор книги «Искусство Русского Севера»: «Лето 1903 года В.В. Переплётчиков провел в селениях под Архангельском, писал почти ежедневно, создал ряд пейзажей. Выразительностью решения отличается его произведение "Селение Усть-Пинега на Северной Двине”, где за бревенчатыми постройками виднеются горы-“вараки”, да окутанные туманом дали. На полотне "Селение Ухтостров Архангельской губернии" горделиво господствует величественный каменный храм, а рядом с ним ютятся покосившиеся избы и сараи, показаны беспорядочно сложенные старые бревна, что правдиво передает облик погибающей северной деревни» [13, с. 249].

История создания многих картин В.В. Переплётчикова утрачена, некоторые его пейзажи не датированы. Но можно попытаться восстановить некоторые факты жизни художника, уточнить атрибуции его произведений. Один из недатированных малоизвестных пейзажей «Вид с Лахты» находится в запасниках Великоустюгского государственного историкоархитектурного и художественного музеязаповедника. Эта работа занимает очень важное место в творчестве В.В. Переплётчикова. По мнению Е.А. Скоробогачевой, «...этюды к картине могли быть написаны в июле 1903 года. Пейзаж "Вид с Лахты”, несомненно, потребовал нескольких сеансов работы. Его художник мог писать и во время северной поездки, и после возвращения в Москву. В отличие, например, от И.И. Левитана, В.В. Переплётчиков не писал картины по воспоминаниям в течение нескольких лет, а создавал их по свежим впечатлениям. Должно быть, полотно написано в том же 1903 году. На Передвижных выставках художник ее не показывал, как и другие северные работы» [13, c. 253].

В 1904 году художник обращается к новому для него методу - дивизионизму. На выставке
Союза русских художников 1905 года он выставляет картины «Осенью», «В лесу осенью» как результат новых исканий [7, с. 18]. Художник здесь пользуется дробным мазком, несколько суховатым, похожим, кстати, на живопись И.Э. Грабаря, картина которого «Февральская лазурь» выставлялась на этой же выставке [7, с. 18]. Несмотря на обращение к новым приемам, художник не теряет предметности изображаемого. Его новые работы скромны, они повторяют типичные для В.В. Переплётчикова мотивы среднерусской природы. Скорее всего, это первые опыты художника по освоению нового для него принципа. Увлечение дивизионизмом оказалось нестойким, хотя В.В. Переплётчиков по-прежнему ищет более выразительного живописного воплощения природы.

В этом отношении он явный представитель Союза русских художников, а точнее, московского его крыла, более демократичного, крепче связанного с традициями московской пейзажной школы. Художник много путешествует. Он изъездил всю половину России: побывал в Тульской, Костромской, Ярославской, Самарской, Уфимской, Владимирской, Калужской, Нижегородской, Новгородской, Вологодской, Архангельской губерниях. Путешествия не прошли для него без следа, кругозор художника заметно расширился. Страну он видит глазами не путешественника, а как бы рядового россиянина. Он чувствует, переживает события с позиций простого народа. Интерес и внимание к российской действительности, к русским людям, живущим на обширных пространствах страны, ощущается и в его дневниках. И.Э. Грабарь называет художника «искателем России» [7, с. 19].

Это определение относится не только к поискам В.В. Переплётчиковым новых мотивов, но и к постоянному побуждению раскрыть своеобразие русской природы, воспринятой простым человеком. В больших циклах северных пейзажей 1907-1913 годов дана широкая картина природы севера России. Достаточно лишь взять ряд картин разного времени («Михайловское озеро Архангельской губернии после дождя», «Северная деревня», «Околица», «Цветы севера», «Селение Порог на реке Вонгуде», «Деревня Порог», «У большой реки»), чтобы почувствовать глубоко национальный характер творчества В.В. Переплётчикова [7, с. 19] (рис. 6, 7, 8).

Художник выбирает известные каждому русскому пейзажные мотивы, однако цветовое решение их не всегда простое. Такова его синяя «Деревня Порог», изображенная на фоне яркого гаснущего заката [7, с. 19]. В этой картине, по тону более сильной и звучной, чем предыдущие, нет ничего от импрессионистических 

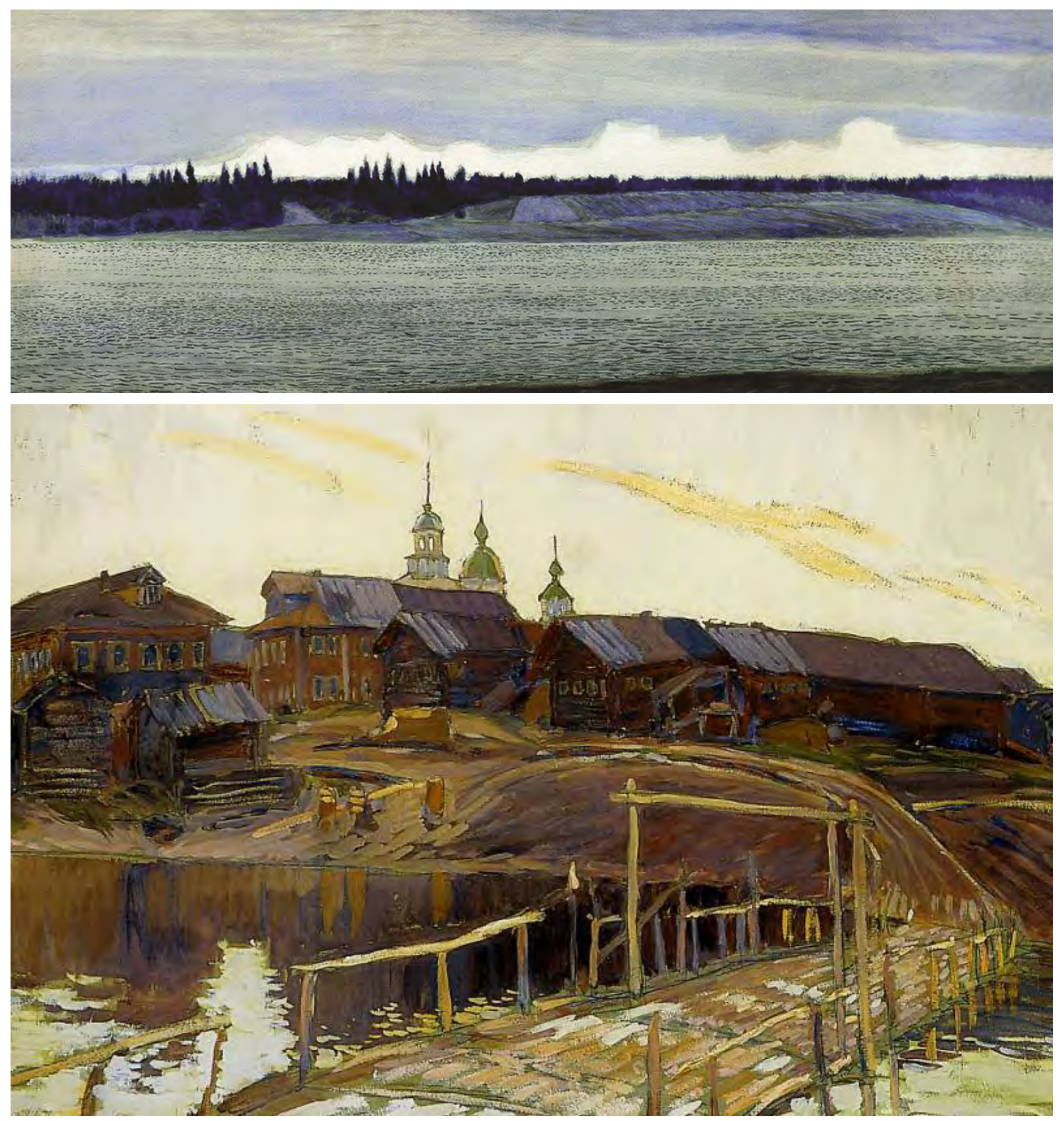

поисков. Скорее всего, художник здесь вернулся к идейной стороне изобразительного искусства, материальности (реальности) изображаемых предметов. Обычная северная деревня приобретает значительность, вырастая призрачными фиолетовыми избами, четко рисуемыми на ярком оранжевом полотне неба. Более типична полуэтюд, или полукартина, «У большой реки» [7, с. 20]. Это одна из тех работ, которая была сделана на Северной Двине. Незамысловатая крестьянская изба с вывешенным под окном бельем, сидящая женщина на высоком крыльце. Широкое раздолье с плавной рекой сливается на горизонте с бледно-синей дымкой бескрайних лесов. В этюде, сохраняющем свежесть красок северной природы, четко ощущается народнесколько созерцательное любование родной природой - всё передает в художнике мастера национальной школы. ный дух. И сам крестьянский мотив, и русское,
6. В.В. Переплетчиков. Михайловское озеро Архангельской губернии после дождя. 1907.

Бумага, акварель.

$36 \times 94$.

Ставропольский краевой музей изобразительных искусств.

Фото: petroart.ru

7. В.В. Переплетчиков. Селение Порог на реке Вонгуде.

1911.

Картон, гуашь. Государственная Третьяковская галерея. Фото: kola.gallery 


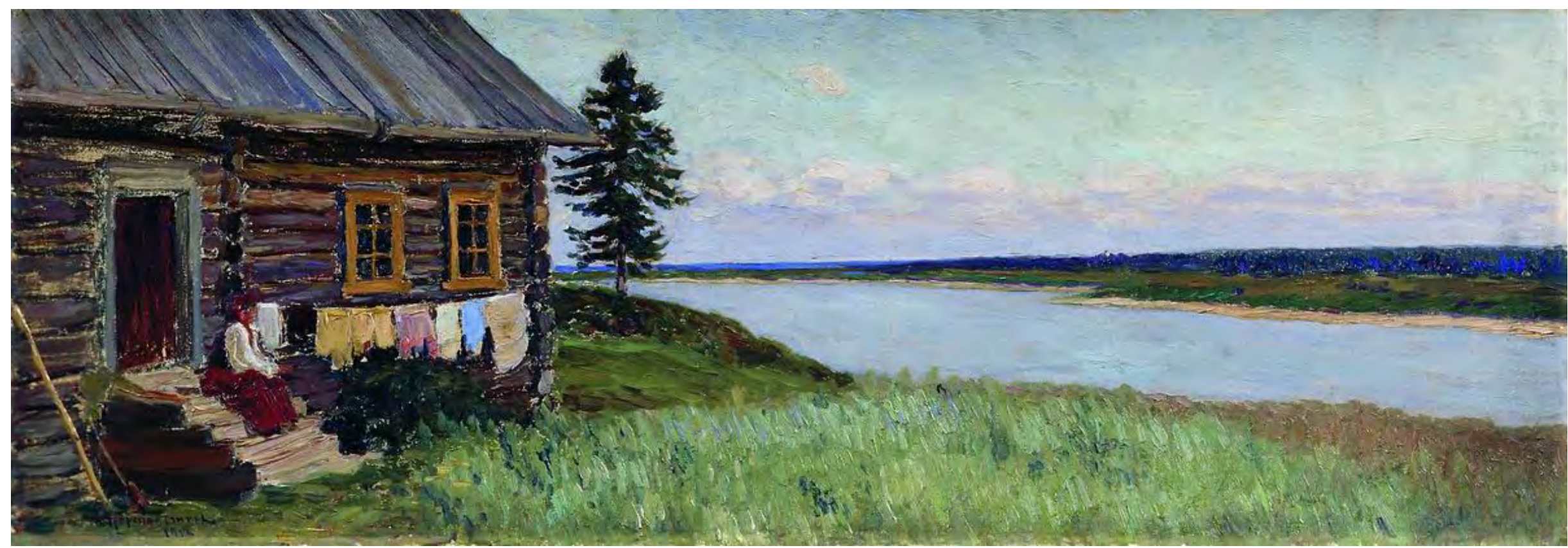

8. В.В. Переплетчиков. у большой реки.

1912.

Картон, масло.

$34 \times 94$.

Иркутский областной

художественный музей имени В.П. Сукачёва. Фото: art-catalog.ru
В.В. Переплётчиков - один из немногих художников, обращавшихся к северным интерьерам. Он написал работу «Комната в Сийском монастыре» (по-видимому, картина имела разные названия: «Тишина моей комнаты. Сийскийский монастырь», «Вид из моей комнаты в АнтониевоСийском монастыре», «Интерьер. Рисунок»). Здесь мы видим открытое окно, через которое видны дали, а свежий ветер едва кольшет скатерть, перебирает листы книги, оставленной на столе. Скромна и обычна комната, не очень характерен для Севера пейзаж за окном, и тем не менее создан запоминающийся образ.

В 1913 году В.В. Переплётчиков на борту парохода «Ольга» совершает двухнедельный рейс по Ледовитому океану [7, с. 22]. Он жил на Новой Земле, подобно А.А. Борисову, писал пролив Маточкин Шар и по-прежнему вел дневник. «На Новой земле он посещает становище "самоедов" "Белужья губа", где обитал его ученик Тыко Вылка, добирается до самого северного европейского поселения "Ольгинское становище”, пытается разыскать следы пропавших экспедиций В.А. Русанова, Г.Я. Седова и т.д. Возвращаясь на большую землю, он занимается просветительской работой, читает о Севере лекции, публикует дневниковые записи, сделанные там» [12] (см. также [1]). Результатом летней поездки на борту «Ольги» явился не только его очерк «Новая Земля», опубликованный в журнале «Заветы», но и серия этюдов и картин, выставленная на XI выставке Союза русских художников «Пролив Маточкин Шар», «Север. Новая Земля», «Становище Малые Карманкулы», «Гора Пила в проливе Маточкин Шар» и др. [8]. В отличие от его литературных строк его пейзажам нередко свойственны излишняя сухость манеры, однообразие композиций и цветовых сочетаний. Неизведанные земли словно бы подсказывали новые важные темы. Арктические пейзажи были необычны для В.В. Переплётчикова. Если его северодвинским работам было присуще драматическое восприятие природы, то в изображении сурового острова Ледовитого океана звучат трагические ноты. Очертания серых волнистых берегов, тяжелая свинцовая вода Северного моря оставляют впечатление пустынного одиночества, сурового безмолвия, потерянности и заброшенности человеческой души. Новые пейзажи художника неторопливо повествовательны, как, впрочем, все его северные работы. Соединенные вместе, они вырастают в значительную художественную эпопею, повествующую о бескрайних просторах и своеобразной суровой красоте заполярного края. В 1914-1918-х годах во время Первой мировой войны, которая сильно ограничила его возможности путешествий, В.В. Переплётчиков обращается к видам Москвы и Подмосковья (например, «Вид Москвы», 1909, рис. 9). На его картинах и этюдах появляются аллеи Нескучного сада, живописная река Клязьма и скромные верховья Москвы-реки солнечной весной и в пасмурный день. Новые пейзажи лишены эпического характера северных картин, они всё более замыкаются в круг этюдов.

Произведения Переплётчикова пользовались известностью, «об одной из них - “Над Двиной надвигается буря" (1908) - И.Э. Грабарь говорил в 1909 году как о "значительной картине". Именно эту работу и другую — "Черемуха цветет” (1915; рис. 10) - Совет Третьяковской галереи приобрел в 1916 году для своего собрания» [12]. Частный, внешне незначительный мотив В.В. Переплётчиков 

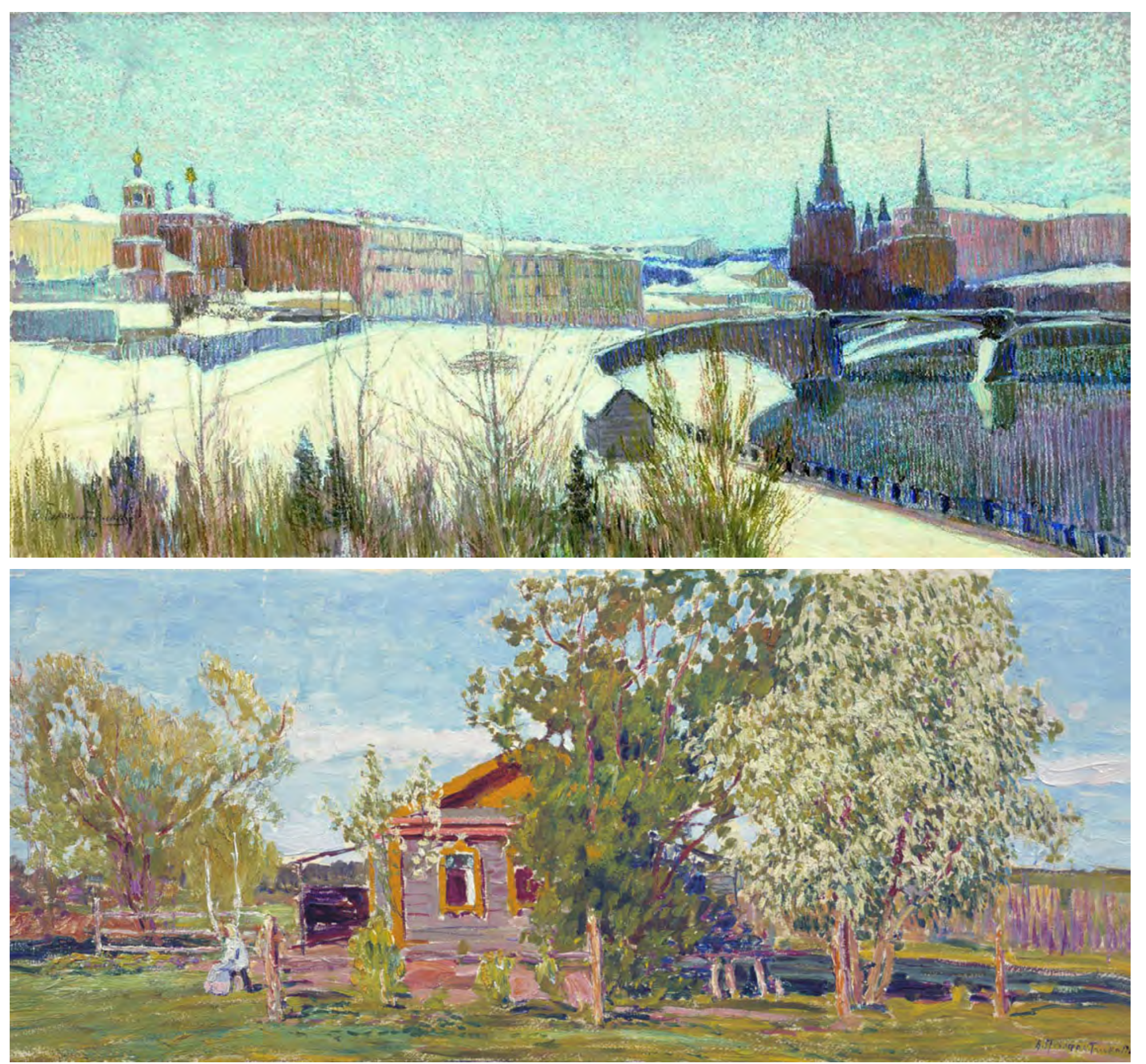

9. В.В. Переплетчиков. Вид Москвы.

1909.

Картон, пастель.

$45,5 \times 92$.

Воронежский областной художественный музей имени И.Н. Крамского. Фото: yavarda.ru

\section{0. В.В. Переплетчиков.} Черемуха цветет. 1915.

Холст, масло.

Государственная Третьяковская галерея. Фото: artpoisk.info в картине «Черемуха цветет» насытил свежим ощущением весны, цветением, радостью жизни. Сохраняется высветленная гамма цвета, как будто бы просвечивается светлый грунт холста - свидетельство новой яркой и красочной живописи, утвержденной в русском искусстве художниками Союза. В собрание Нижегородского государственного художественного музея относительно недавно был приобретен пейзаж, датированный 1917 годом, владельцы которого считали, что это вид Ясной Поляны.

Большую часть своего бытования пейзаж В.В. Переплётчикова находился в собственности брата активного деятеля революционной эпохи - А.И. Пискунова - Флегонта Ивановича. По воспоминаниям близких, картину любили, она вызывала светлые, поэтические чувства. В 1999 году картина вошла в экспозицию выставки «Пушкинская Россия: портреты современников, усадебный пейзаж, интерьер» [5, с. 173]. Правда, при оформлении музейной документации полотно получило нейтральное, ни к чему не обязывающее название «Пейзаж с белым домом», поскольку последние владельцы, уже третьи после Ф.И. Пискунова, ничего конкретного сообщить о картине тоже не смогли. Но действительно ли это изображение Ясной Поляны? Судя по сохранившимся постройкам, ландшафту, а также старым описаниям, в картине В.В. Переплётчикова изображена подмосковная усадьба Гребнево. Точнее, небольшая ее 
часть с фрагментом левого двухэтажного флигеля, примыкающего к ограде французского парка с боковыми воротами в виде двух пилонов с ионическими колоннами. «Пейзаж с белым домом» занял свое законное место среди произведений Серебряного века на усадебную тему [5, с. 174]. По-видимому, это было одним из последних прижизненных произведений автора. В 1918 году в Москве В.В. Переплётчикова не стало.

\section{Заключение и выводы}

На основе проведенного исследования мы можем заключить, что В.В. Переплётчиков воплотил свои замыслы в различных сферах изобразительного искусства, литературы. Его энергия и инициатива в устроении художественной жизни не позволяли ему сконцентрироваться на чем-нибудь одном, чтобы всецело посвятить себя избранному роду занятий, впрочем, создается впечатление, что он совсем не стремился заключить свои интересы в какие-либо рамки. Художника влекли путешествия, что дало возможность проявить себя в качестве очеркиста, а также интересовали новые течения в живописи. В статье показана эволюция пейзажа в творчестве В.В. Переплётчикова. Выставки, где представлены работы В.В. Переплётчикова, почти не обходятся без северных пейзажей, весьма многочисленных и разнообразных. Светлая гамма красок, которой художник упорно добивается, приводит его к применению новых для него техник. Он пишет темперой, гуашью, акварелью, сохраняя прежнее пристрастие к масляной живописи. Во время поездки В.В. Переплётчикова по северу России исследователь Стивен Грим встретился с художником и дал очень точную характеристику его творчества этого периода: «В.В. Переплётчиков принадлежит к числу художников-импрессионистов. Его интересует более не форма, а душа того, что он видит. Его цель и стремление дать в своих картинах представление о настроениях природы. ..» [7, с. 18]. 


\section{Литература}

1. Вылка Т. Записки о Новой земле / вступ. ст. В.В. Переплётчикова. Москва: графическое заведение «Друкарь», 1914.16 с.

2. Дудаков В.А. Выставка шести // Художник. 1991. № 12. С. 39-43.

3. Лапшин В.П. Василий Васильевич Переплётчиков. Художник. Путешественник. Литератор. Общественный деятель // Русское искусство. 2004. № 1. С. 47-57. URL: http://russiskusstvo.ru/journal/1-2004/a633 (дата обращения: 27.04.2021).

4. Лапшин В.П. Союз русских художников. Ленинград: Художник РСФСР, 1974. 420 с.

5. Миронова И.В. «Эта прекрасная повесть о минувшем». Усадебные мотивы в произведениях Серебряного века (из собрания НГХМ) // ІІІ Музейные научные чтения «Мир русской усадьбы», 6-7 ноября 2006 г.: Сборник материалов. Нижний Новгород: Деком, 2007. С. 163-182.

6. Московские художники конца XIX - начала XX века: С. Виноградов, Н. Досекин, Е. Каменцева, Н. Клодт, К. Первухин,

В. Переплётчиков: каталог выставки / сост. Б.М. Одинцов. [Москва]: СФК. Дирекция выставок и аукционов, [1990?]. 44 с.

7. Переплётчиков В.В. Дневник художника; Очерки, 1886-1915 / ред.-сост. Манин В.С. Москва: Союз Дизайн, 2012.419 с.

8. Переплётчиков В.В. Новая Земля // Заветы. 1914. № 7. С. 73-114.

9. Переплётчиков В.В. Рисунки В.В. Переплётчикова. Москва: [б. и.], 1891. [10] л.

10. Переплётчиков В.В. Север: Очерки русской действительности / с 16 репрод. картин и рис. В.В. Переплётчикова. Москва: Книгоизд-во писателей, 1917. 180 с.

11. Переплётчиков В.В. Север: очерки русской действительности. Москва: Терра: Книжный Клуб Книговек, 2019.156 с.

12. Переплётчиков Василий Васильевич // Artcyclopedia.ru: энциклопедия русской живописи [сайт]. 2011.

URL: http://www.artcyclopedia.ru/perepletchikov_vasilij_vasilevich.htm (дата обращения: 22.05.2021).

13. Скоробогачева Е.А. Искусство Русского Севера. Москва: Белый город, 2008. 303 с.

14. Скоробогачева Е.А. Образы Русского Севера // Провинция в контексте истории и литературы: материалы III Крапивенской конференции / гл. ред. В.И. Толстой; ред. Н.В. Свиридов. Тула: Ясная Поляна, 2007. С. 123-135.

15. Скоробогачева Е.А. Художественные традиции Русского Севера в отечественном искусстве последней трети XIX - начала XX века: автореферат дис. ... канд. искусствоведения. Саранск, 2013. 25 с.

16. Стернин Г.Ю. Художественная жизнь России начала XX века. Москва: Искусство, 1976. 221 с.

17. Федотова А.В. Роль художников в развитии Русского Севера // Наука и современность. 2011. № 11. С. 114-118.

URL: http://cyberleninka.ru/article/n/rol-hudozhnikov-v-razvitii-russkogo-severa (дата обращения: 01.05.2021).

18. Чижмак М.С. Выставочная деятельность Московского товарищества художников 1890-х годов // Третьяковские чтения.

2013: материалы отчетной научной конференции. Москва: Государственная Третьяковская галерея, 2014. С. $152-168$.

ИНФОРМАЦИЯ ОБ АВТОРЕ: Филиппова Ольга Николаевна - искусствовед, заведующая научным архивом, Политехнический музей, г. Москва, Российская Федерация. ORCID: 0000-0002-8933-1214. E-mail: iscusstvo0891@mail.ru

ABOUT AUTHOR: Filippova Olga Nikolaevna - Head of the scientific archive, the Polytechnic Museum, Moscow, Russian Federation. ORCID: 0000-0002-8933-1214. E-mail: iscusstvo0891@mail.ru 


\section{References}

1. Vylka T. Zapiski o Novoj zemle [Notes on Novaya Zemlya]. Moscow, Drukar, , 1914. 16 p. (In Russian).

2. Dudakov V.A. Vystavka shesti [Exhibition of six]. Hudozhnik - Artist, 1991, No. 12, pp. 39-43. (In Russian).

3. Lapshin V.P. Vasily Vasilievich Perepletchikov. Hudozhnik. Puteshestvennik. Literator. Obschestvennyj dejatel' [Vasily Vasilievich

Perepletchikov. Artist. Traveler. Writer. Public figure]. Russkoe iskusstvo - Russian art, 2004, No. 1, pp. 47-57.

Available at: http://russiskusstvo.ru/journal/1-2004/a633 (accessed: 27.04.2021). (In Russian).

4. Lapshin V.P. Sojuz russkih hudozhnikov [Union of Russian Artists]. Leningrad, Hudozhnik RSFSR Publ., 1974. 420 p. (In Russian).

5. Mironova I.V. «Eta prekrasnaja povest' o minuvshem». Usadebnye motivy v proizvedenijah Serebrjanogo veka (iz sobranija NGHM)

["This is a wonderful tale of the past.» Manor motifs in the works of the Silver Age (from the collection of the Novosibirsk State Art

Museum)]. III Muzejnye nauchnye chtenija «Mir russkoj usad'by» [III Museum Scientific Readings «The World of the Russian Manor»].

Novgorod, Dekom, 2007, pp. 163-182. (In Russian).

6. Odintsov B.M. (comp.). Moskovskie hudozhniki kontsa XIX - nachala XX veka: S. Vinogradov, N. Dosekin, E. Kamentseva, N. Klodt, K. Pervuhin, V. Perepletchikov: katalog vystavki [Moscow artists of the late 19th - early 20th century: S. Vinogradov, N. Dosekin, E. Kamentseva, N. Klodt, K. Pervukhin, V. Perepletchikov: exhibition catalog]. Moscow, SFK. Direktsija vystavok i auktsionov, 1990. 44 p. (In Russian).

7. Perepletchikov V.V. Dnevnik hudozhnika; Ocherki, 1886-1915 [The artist's diary; Essays, 1886-1915]. Moscow, Sojuz Dizajn, 2012. 419 p. (In Russian).

8. Perepletchikov V.V. Novaya Zemlya [New Earth]. Zavety - Testaments, 1914, No. 7, pp. 73-114. (In Russian).

9. Perepljotchikov V.V. Risunki V.V. Perepljotchikova [Drawings by V.V. Perepletchikov] Moscow, S. n., 1891. 10 p. (In Russian).

10. Perepletchikov V.V. Sever: Ocherki russkoj dejstvitel'nosti [North: Essays on Russian reality]. Moscow, Knigoizdatelstvo pisatelej Publ, 1917. 180 p. (In Russian).

11. Perepletchikov V.V. Sever: Ocherki russkoj dejstvitel'nosti [North: Essays on Russian reality]. Moscow, Terra Publ, 2019.156 p. (In Russian).

12. Perepletchikov Vasily Vasilyevich. Artcyclopedia.ru: encyclopedia of Russian painting.

Available at: http://www.artcyclopedia.ru/perepletchikov_vasilij_vasilevich.htm (accessed: 22.05.2021). (In Russian).

13. Skorobogacheva E.A. Iskusstvo Russkogo Severa [Art of the Russian North]. Moscow, Bely gorod Publ., 2008. 303 p. (In Russian).

14. Skorobogacheva E.A. Obrazy Russkogo Severa [Images of the Russian North]. In: Tolstoy V.I., Sviridov N.V. (eds.). Provintsija v kontekste istorii i literatury [Proceedings of conference "Province in the context of history and literature"]. Tula, Jasnaja Poljana Publ., 2007, pp. 123-135. (In Russian).

15. Skorobogacheva E.A. Hudozhestvennye traditsii Russkogo Severa $v$ otechestvennom iskusstve poslednej treti XIX - nachala XX veka [Artistic traditions of the Russian North in Russian art of the last third of the 19th - early 20th centuries. Cand. Art sci. diss. Abstr.]. Saransk, S. n., 2013. 25 p. (In Russian).

16. Sternin G.Y. Hudozhestvennaja zhizn' Rossii nachala XX veka [Artistic life of Russia at the beginning of the 20th century]. Moscow, Iskusstvo, 1976. 221 p. (In Russian).

17. Fedotova A.V. Rol' hudozhnikov v razvitii Russkogo Severa [The role of artists in the development of the Russian North]. Nauka i sovremennost' - Science and Modernity, 2011, No. 11, pp. 114-118.

Available at: http://cyberleninka.ru/article/n/rol-hudozhnikov-v-razvitii-russkogo-severa (accessed: 01.05.2021). (In Russian). 19. Chizhmak M.S. Vystavochnaja dejatel'nost' Moskovskogo tovarischestva hudozhnikov 1890-h godov [Exhibition activities of the Moscow Association of Artists of the 1890s]. // Tret'jakovskie chtenija [Proceedings of conference "Tretyakov Readings. 2013"]. Moscow, State Tretyakov Gallery, 2014, pp. 152-168. (In Russian).

\section{Для цитирования |For citation:}

Филиппова О.Н. Пейзаж в творчестве Василия Переплётчикова // Искусство Евразии [Электронный журнал]. 2021. № 2 (21). C. 32-45. DOI: https://doi.org/10.46748/ARTEURAS.2021.02.003. URL: https://eurasia-art.ru/index.php/art/article/view/736

Filippova O.N. Landscape in the creative work of Vasily Perepletchikov. Iskusstvo Evrazii - The Art of Eurasia, 2021, No. 2 (21), pp. 32-45. DOl: https://doi.org/10.46748/ARTEURAS.2021.02.003. Available at: https://eurasia-art.ru/index.php/art/article/view/736 (In Russian). 